\title{
THE EFFECTS ON SOIL COMPACTION OF TIMBER SKIDDING BY TRACTOR ON SKID ROAD IN PLANTATION FOREST IN NORTHERN TURKEY
}

\author{
UTJECAJ PRIVLAČENJA DRVA TRAKTOROM NA ZBIJANJE \\ TLA NA TRAKTORSKIM VLAKAMA I PUTEVIMA U \\ PLANTAŽNIIM ŠUMAMA SJEVERNE TURSKE
}

TOLGA OZTURK

\begin{abstract}
SUMMARY
In this study, degree of soil compaction and rutting caused on the skid road by rubber-tired tractor was investigated in northern pine plantation forest in Turkey. In research area, the cross sections were selected in every 20 meter along the skid road. Penetrometer measurements were made in each cross section. Also, the soil samples were collected to on the skid road and forest site. The rutting was measured in each cross section. The results of in this study, on the skid road had shown changes of soil depth and soil compaction during skidding operations. The major soil compaction was also more occurred in the first four passes. The rutting has been less by increasing the number of passes on the skid road. Rut depth became significant after 4th, 8th, 12th, 16th and 20th passes, reaching an average 2.6, 3.5, 4.1, 4.6 and $4.9 \mathrm{~cm}$, respectively. The values penetrometer were found on skid road for every cross section ( 5 different points) and also, on forest soil at edge of skid road (1 point). The soil compaction values were evaluated due to penetrometer measurements.
\end{abstract}

KEY WORDS: soil compaction, rutting, skidding, skid road

\section{INTRODUCTION}

UVOD

Logging is perceived to be one of the major causes of damage to forest vegetation (Alexander, 2012). The planning operations for wood extraction require careful consideration not only to minimize cost but also to reduce the negative impacts on forest soil. Soil disturbance can be described as changes in the forest soil properties. Forest harvesting operations have high potentials for soil disturbances since heavy forestry machines trigger soil compaction due to exerted normal pressure, shear stress, and vibrations (Ampoorter et al., 2007; Jamshidi et al., 2008; Labelle and Jaeger, 2011). The impacts on the physical properties of the soil reduce the soil air capacity (Schnurr et al., 2006), decrease soil infiltration (Ares et al. 2005), and reduce root growth (Jacobsen and Greacen, 1985).

The impact of harvesting operations on forest soils can be categorized as soil compaction, lateral soil displacement, soil puddling and rutting (Majnounian and Jourgholami, 2013). Soil compaction can also affect the long-term pro-

* Dr. sc. Tolga Ozturk, Istanbul University, Faculty of Forestry, Department of Forest Construction and Transportation, 34473, Bahcekoy, Istanbul, Turkey, tozturk@ istanbul.edu.tr 


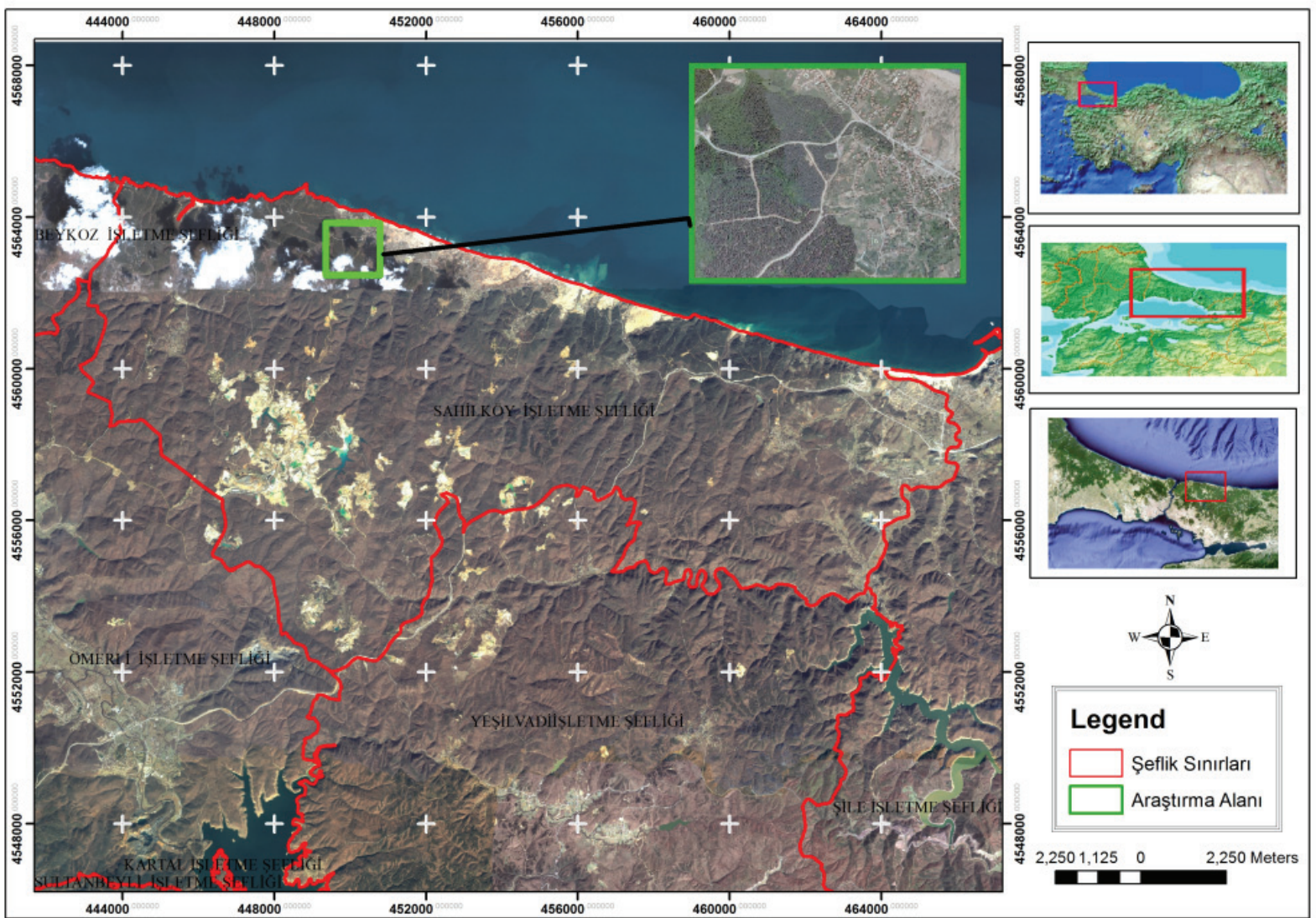

Figure 1. Study area

Slika 2. Područje istraživanja

ductivity of a stand's soil and alter hydorology (Wang et al., 2004). Skidders, tractors, and other machines used in harvesting operations may affect forest soils considerably, mainly depending on terrain conditions, soil characteristics, soil moisture content, and vehicle types (Akay et al., 2007b). Besides, the gross weight of the vehicle, tire size and air pressure in the tires, travel speeds, and number of passes are the operational factors that affect severity of soil compaction (Greene and Stuart, 1985; Susnjar et al., 2006). Studies reported that one of the critical factors affecting the degree of soil compaction is the number of machine passes over a specific point (Majnounian and Jourgholami, 2013). Most compaction occurs during the first ten passes of a vehicle with the most occurring in the firt three passes. Subsequent passes generally have little additional effect (Ampoorter et al., 2007). The major soil disturbance usually occurs during the first passes of machinery and increases by the number of passes (Gayoso and Iroume, 1991). Most compaction occurred after the initial few passes (Matangaran and Kobayashi, 1999). Other studies reported that the most significant soil compaction occurs after 18 skidder passes (Lotfalian and Parsakhoo, 2009) and Naghdi et al. (2007) studied the soil compaction on two types of soils following the timber skidding and they found out that the critical change in the soil's bulk density occurred at the $11^{\text {th }}$ pass of the skidder (Muntenau and Apafaian, 2015).
Operation period and selected machinery can make a big difference in protecting the soil from potential damages (Sutherland, 2003). During periods when soil is wet, heavy harvesting machines with rubber-tires generate deep ruts over forest soil, which leads to several problems such as excessive delays in operations, serious impacts on physical properties of forest soil and damages on tree roots (Akay and Erdas, 2007). Rutting occurs when soil strength is not sufficient to support the applied load from vehicle traffic (Lotfalian and Parsakhoo, 2009).

In Turkey, timber extraction is mainly done by farm tractors. The farm tractors equipped with winch are widely used for skidding operations in mountainous regions (Ozturk, 2014; Melemez, 2010). This study aims to investigate soil displacement and rutting on the skid road caused by a rubber-tired tractor during timber skidding in maritime pine (Pinus pinaster A.) plantation forest of Istanbul, Turkey.

\section{MATERIALS AND METHODS MATERIJALI I METODE}

\section{Study Area - Područje, mjesto istraživanja}

Study area was located in Sile Forest Administration in northern Turkey, management unit Sahilkoy forest compartment 37 (Fig.1). The study area mainly lies on north aspect 
with altitude ranging between $250 \mathrm{~m}$ and $300 \mathrm{~m}$ above the sea level. The average monthly total rainfall for July, June and August in this region was $35.0,31.6$ and $40.7 \mathrm{~kg} / \mathrm{m}^{2}$, respectively. The study area covered 3000 hectares of a 25 years old plantation of the maritime pine (Pinus pinaster A.). The plantation is harvested in rotation usually for every 25-30 years. Soil types are clay in this region.

Skidding operation was performed by a farm tractor on skid road. During skidding, one end of the load is lifted clear from the ground and set on the back of the tractor while other end is skidded on the skid road. The slope of skid road was changed between 2 and 12 percent and the length of skid road is $280 \mathrm{~m}$. The logging operation was performed by tree-length method where the stems were skidded to the roadside landings by farm tractor after the trees were felled, delimbed and topped at the stump area.

\section{Technical Features of Tractor - Techničke znacajke traktora}

Massey Ferguson 285 farm tractor was used in timber extraction. This tractor was used for skidding operation and it's has back-lift system. During skidding operation, one end of the $\log$ was elevated on the back- lift system while other and of log was pulled on the ground (Fig. 2). Tractor was equipped with a cab to protect operator and to minimize noise level. The rear tires were larger than the front tires in width and in diameter. The dimension number of front and rear tires was 12.4-24PR12 and 18.4-30PR14, respectively. The width of the rear and front tires were 30 and $24 \mathrm{~cm}$, respectively and their air pressure was $16 \mathrm{psi}$. The main technical features of the tractor were shown in Table 1.

\section{Data Collection - Prikupljanje podataka}

The total length of skid road was measured as $280 \mathrm{~m}$. The slope of skid road was changed $2-12 \%$. In this plantation area, the average length and diameter of the skidded stems were $16 \mathrm{~m}$ and $32 \mathrm{~cm}$, respectively.

There were fourteen cross sections on skid road. On each cross section, soil compaction and rutting were examined

Table 1. Technical specifications of the tractor

Tablica 1. Tehničke značajke traktora

$\begin{array}{ll}\text { Technical features - Tehničke karakteristike } & \\ \text { Brand - Model } & \text { Massey Ferguson } 285 \\ \text { Motor power - Snaga motora } & 82 \mathrm{HP} \\ \text { Motor type - Tip motora } & \text { Perkins } \\ \text { Cylinder number - Broj cilindara } & 4 \\ \text { Cylinder volume - Zapremnina cilindra } & 4.06 \mathrm{liter} \\ \text { Max. Torque - } & 1400 \text { revolution per min. } \\ \text { Maks. okretni moment } & 1400 \text { okr. po min. } \\ \text { Max. Revolution (Unload) - } & 2160 \text { revolution per min. } \\ \text { Maks. br. okr. (bez opterećenja) } & 2160 \text { okr. po min. } \\ \text { Empty weight - Prazna težina } & 3470 \mathrm{~kg}\end{array}$

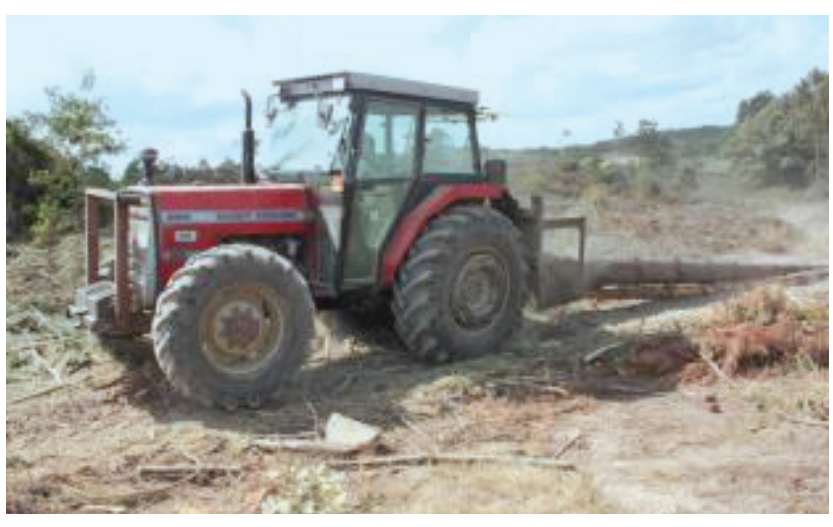

Figure 2. Timber skidding by farm tractor

Slika 2. Privlacenje drva traktorom

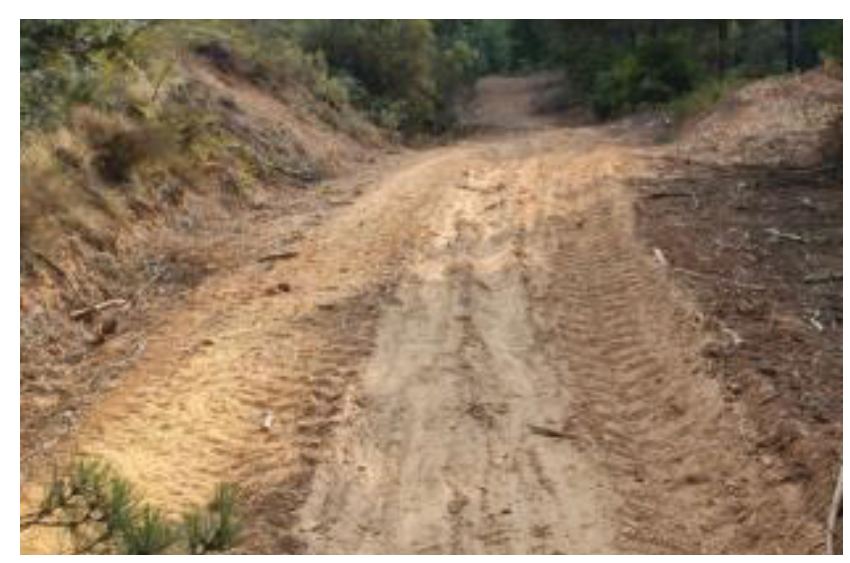

Figure 3. Field measurement points on cross section on skid road Slika 3. Mjerne točke na presjecima traktorskih vlaka

and recorded for various numbers of tractor passes (4th, 8th, 12th, 16th and 20th passes) along the skid road (Fig. 3).

Deformation dimensions on skid road were measured with the steel tape and ruler. The distance between cross sections was measured by using measuring wheel. The each cross section shape was measured on the skid road. Then, the shapes of cross section were written in AutoCad program. The soil distribution area was calculated for each cross section. The compaction of soil was measured by a hand penetrometer. In this study, matest proving ring penetrometer was used. The measured depth of this penetrometer is 50 $\mathrm{cm}$. The soil moisture content was measured a hygrometer. The depth of soil moisture content was changed between 0-15 cm. Besides, soil samples were collected on skid road and from forest site by using steel cylinders to investigate changes on soil properties (weight, texture, and $\mathrm{pH}$ ) on the skid roads and the forest ground. Volume weight, Fine Soil Weight $(<2 \mathrm{~mm})$ and Stone Weight $(>2 \mathrm{~mm})$ (Gulcur, 1974), Soil text (Karaoz, 1992) and pH (Mc Lean, 1982.) were analyzed. For soil samples didn’t show normal distribution, average values were compared with Mann-Whitney U test in one of the nonparametric methods (Kalıpsız 1981; Ozdamar 2002; Senol 2004). 


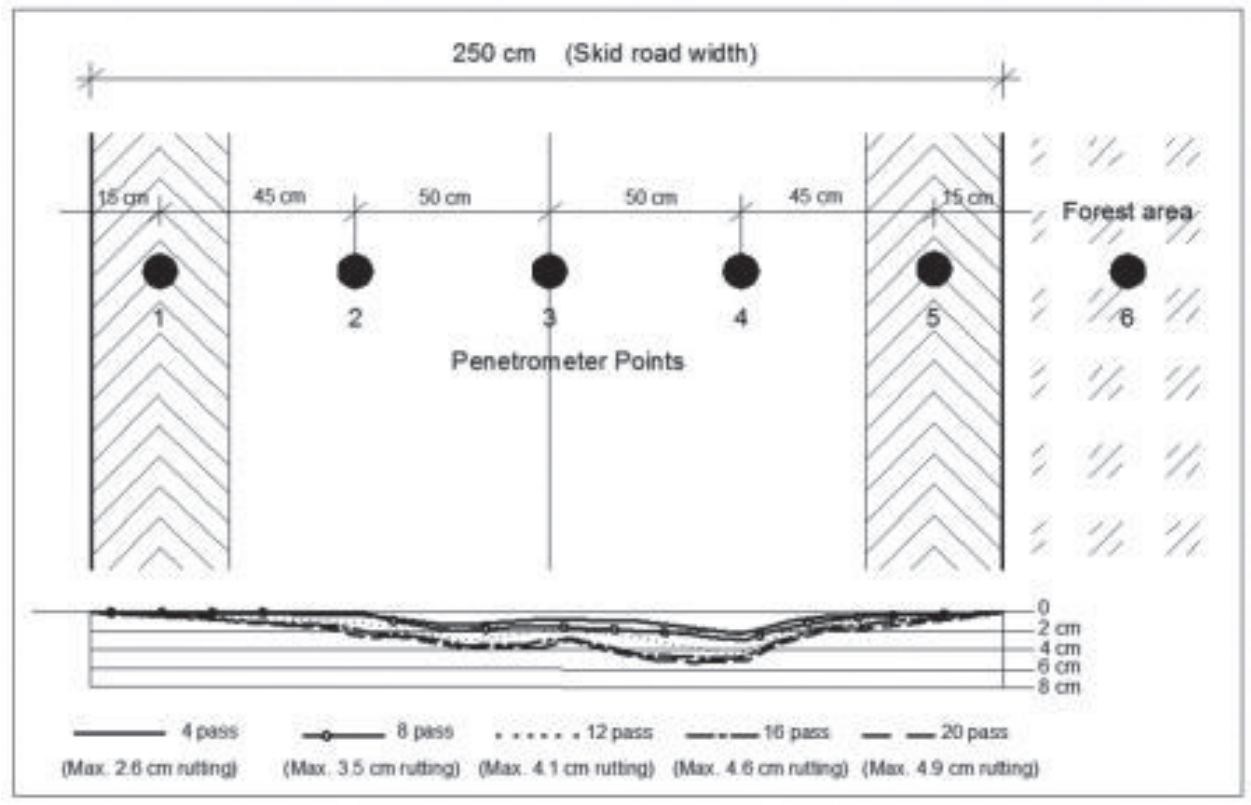

Figure 4. Maximum rut depth changes on skid road because of tractor passes

Slika 4. Maksimalna promjena dubine kolotraga na traktorskim vlakama nastala zbog prolaska traktora

\section{RESULTS AND DISCUSSION REZULTATI I RASPRAVA}

Soil disturbances on skid road during a log skidding operation by a farm tractor were measured considering soil compaction and rut depth formation. Field measurements were made at 14 cross sections along the skid road. The results indicated that soil compaction and rutting increased as number of passes increased. During initial passes, the soils especially on the center of skid road became very dusty, and then dusty ground was removed from the skid road due to factors such as wind, rainfall, and operating vehicles. This process led to soil displacement and gully formation on the skid roads which potentially increased the risk of erosion (Pierzchala et al., 2014).

The results revealed that the amount of soil deformation was generally higher at the center of the skid road as com-

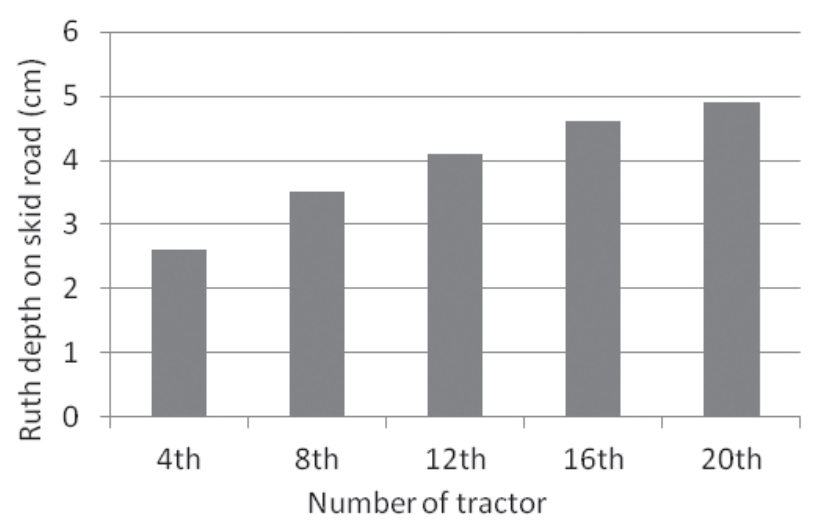

Figure 5. Rut depth variation on skid road during skidding Slika 5. Varijacije dubina kolotraga tijekom privlačenja drva pared to the control points at the edge of skid road. This situation was shown as deformation shape on skid road (Fig.4). Similar to previous studies, the rut depths on skid roads changed mainly depending on the number of passes (Akay et al., 2007a; Alexander, 2012). It was found that average rut depth did not reach to a critical level during the first five passes $(4.0 \mathrm{~cm})$; however, it was dramatically increased by the following passes.

The results indicated that rut depth became more significant after 4th, 8th, 12th, 16th and 20th passes for skid road, reaching a maximum of 2.6, 3.5, 4.1, 4.6 and $4.9 \mathrm{~cm}$, respectively (Fig.5). In a similar study, Erdas (1993) reported average rut depth of $10-15 \mathrm{~cm}$ after 10-20 tractor passes during a log skidding operation.

In this study, every cross section was measured soil compaction values by penetrometer. Also, the compaction values on forest ground were measured to edge of each cross section. The soil compaction and soil disturbance were found to be on the skid road. The average soil compaction was found to be $0,97 \mathrm{kN} / \mathrm{cm}^{2}$ on the center of skid road while the value of soil compaction was $0,54 \mathrm{kN} / \mathrm{cm}^{2}$ on the forest ground (for 20th passes)(Table 2).

The average width of affected surface was found as between 30 and $220 \mathrm{~cm}$ on the skid road. Also, on the right and left sides of skid road were shown changes of soil depth during skidding operations. The results of this study showed that the rut depth and soil compaction developed with increasing of tractor passes. The exchange rate was more found first four passes. Then, this rate was lost (Table 3).

The soil displacement on the skid road was occurred on the each cross section. Dobek et al., (2011) also reported that 
Table 2. The penetrometer values on skid road and forest area (Tukey HSD $p<0,01$ )

Tablica 2. Vrijednosti penetrometra na traktorskoj vlaci i šumskom području

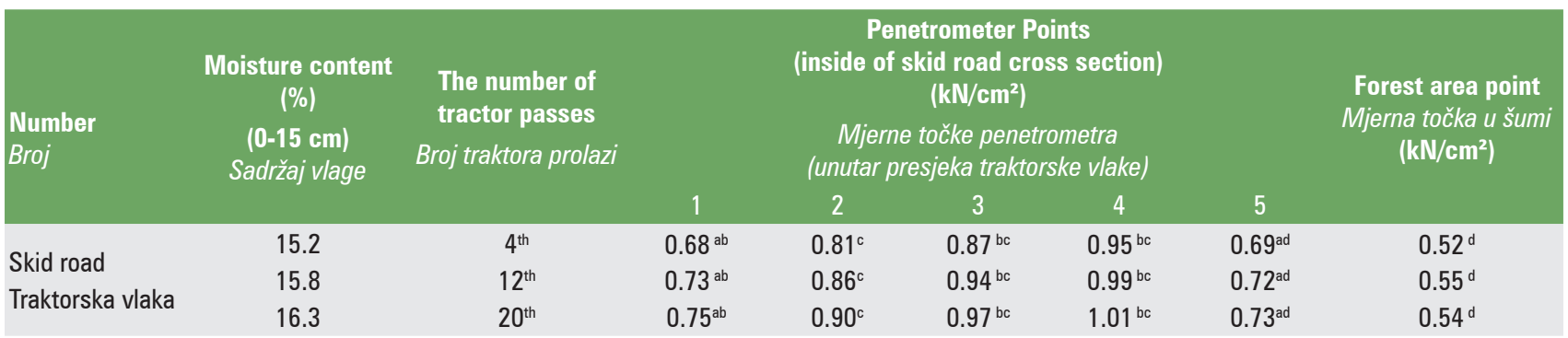

Table 3. The exchange rate on skid road

Tablica 3. Stopa promjene dubine na traktorskoj vlaci

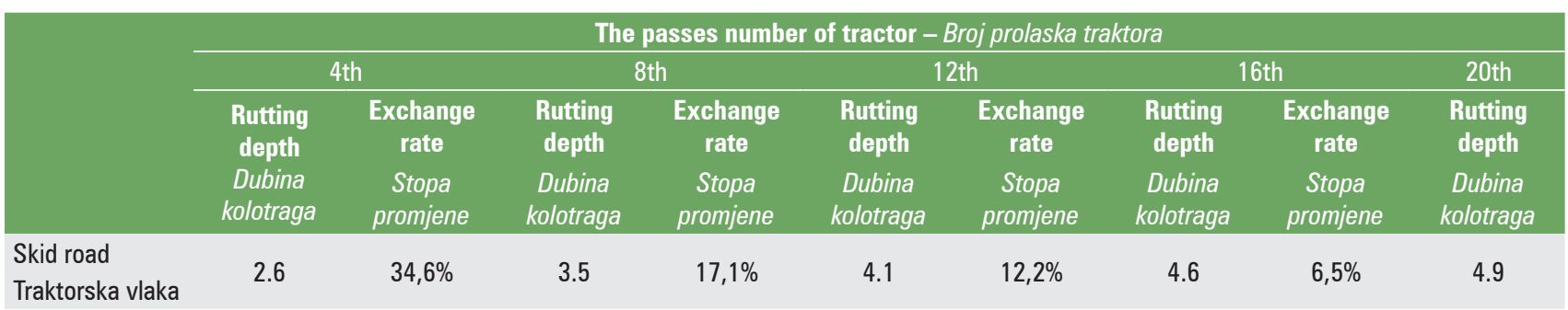

Table 4. Soil characteristics on skid road and forest area (Mann-Whitney $U p<0,01$ )

Tablica 4. Karakteristike tla na traktorskoj vlaci i šumskom području

\begin{tabular}{|c|c|c|c|c|c|c|}
\hline \multirow{2}{*}{$\begin{array}{l}\text { Soil properties } \\
\text { Karakteristike tla }\end{array}$} & \multicolumn{3}{|c|}{$\begin{array}{c}\text { Skid road } \\
\text { Traktorska vlaka }\end{array}$} & \multicolumn{3}{|c|}{$\begin{array}{c}\text { Forest Site } \\
\text { Područje šume }\end{array}$} \\
\hline & $\begin{array}{c}\text { Mean } \\
\text { Srednja vrijednost }\end{array}$ & $\begin{array}{l}\text { Min. } \\
\text { Min. }\end{array}$ & $\begin{array}{l}\text { Max. } \\
\text { Maks. }\end{array}$ & $\begin{array}{c}\text { Mean } \\
\text { Srednja vrijednost }\end{array}$ & $\begin{array}{l}\text { Min. } \\
\text { Min. }\end{array}$ & $\begin{array}{l}\text { Max. } \\
\text { Maks. }\end{array}$ \\
\hline $\begin{array}{l}\text { Volume weight (g/l) } \\
\text { Težina volumena }\end{array}$ & $1362,3^{a}$ & 942,9 & 1969,2 & $1119,2^{\mathrm{a}}$ & 960,2 & 1427,8 \\
\hline $\begin{array}{l}\text { Fine soil weight }(\mathrm{g} / \mathrm{l}) \\
\text { Težina finog tla }\end{array}$ & $1187,6^{\text {a }}$ & 812,8 & 1578,2 & $1037,7^{\mathrm{a}}$ & 877,1 & 1305,4 \\
\hline $\begin{array}{l}\text { Stone weight }(\mathrm{g} / \mathrm{l}) \\
\text { Težina kamenja }\end{array}$ & $174,7^{\mathrm{a}}$ & 48,3 & 480,2 & $81,5^{a}$ & 43,5 & 122,5 \\
\hline $\begin{array}{l}\text { Sand (\%) } \\
\text { Pijesak }\end{array}$ & $64,5^{\mathrm{a}}$ & 53,0 & 71,7 & $68,8^{a}$ & 59,3 & 75,6 \\
\hline $\begin{array}{l}\text { Silt (\%) } \\
\text { Mulj }\end{array}$ & $8,9^{a}$ & 3,5 & 18,8 & $10,9^{a}$ & 5,5 & 16,7 \\
\hline $\begin{array}{l}\text { Clay (\%) } \\
\text { Glina }\end{array}$ & $26,6^{\text {a }}$ & 18,8 & 41,5 & $20,3^{\mathrm{a}}$ & 16,9 & 24,0 \\
\hline $\begin{array}{l}\mathrm{pH} \\
\mathrm{pH}\end{array}$ & $4,8^{\mathrm{a}}$ & 4,5 & 5,2 & $5,3^{b}$ & 5,1 & 5,6 \\
\hline
\end{tabular}

development of gullies related to skidding operation causes runoff concentration along the skidding roads which may lead to the erosion processes.

Soil properties were analyzed soil samples collected from skid road and forest site (Table 4). The results indicated that there was no important difference between skid road and forest site interns of volume weight, soil weight and soil texture values; however, stone weight was higher on skid road samples than that of forest site due to soil displacement along skid road. The $\mathrm{pH}$ value of the soil samples collected from skid road was also higher than that of forest site due to acceleration of the decomposition conditions in skid road. The moisture of soil was very low because of summer months. Also, the soil type was clay and the soil on the skid road was distributed in powder form during skidding operation.

\section{CONCLUSION} ZAKLJUČCI

In this study, soil compaction and rutting on the skid roads during a logging operation were investigated by field measurements after each pass of a farm tractor along skid road. The study showed that the vehicle passes had a significant 
effect on soil compaction. Soil disturbance and rutting from skidding operations are common consequence of soil damage on skid road. Especially, the rutting causes serious erosion problems during heavy rainfalls. After heavy winter conditions and spring rains, erosive power of the surface run-off can create damages on the skid roads.

Skidding operations should be planned to minimize soil compaction. Also, the appropriate machine types and machine sizes should be selected for skidding operations to minimize soil disturbance. In the plantation areas, the skid roads should be rehabilitee by bulldozer and grader. Thus, the risk of erosion is reduced in the years ahead.

\section{REFERENCES}

\section{LITERATURA}

- Akay, A.E., O.Erdas, 2007: Estimating rut depth during skidding with a rubber-tired skidder. Suleyman Demirel University, Journal of Faculty of Forestry, A(1): 49-57.

- Akay, A.E., J. Sessions, K.Aruga, 2007a: Designing a forwarder operation considering tolerable soil disturbance and minimum total cost. Journal of Terramechanics, 44(2): 187-195.

- Akay, A.E., A. Yuksel, M. Reis, A. Tutus, 2007b: The impacts of ground-based logging equipment on forest soil. Polish Journal of Environmental Studies. 16(3): 371-376.

- Alexander, A.B., 2012: Soil compaction on skid trails after selective logging in moist evergreen forest of Ghana. Agriculture and Biology Journal of North America. 3(6): 262-264.

- Ampoorter, E., R.Goris, W.M.Cornelis, K.Verheyen, 2007: Impact of mechanized logging on compaction status of sandy forest soils. Forest Ecology and Management, 241: 162-174.

- Ares, A., T.A.Terry, R.E.Miller, H.W.Anderson, B.L.Flawing, 2005: Ground-based forest harvesting effects on soil physical properties and Douglas-Fir growth. Soil Sci. Am. J. 69: 18221832.

- Dobek, K., P.Demczuk, J.Rodzik, B.Hołub, 2011: Types of gullies and conditions of their development in silvicultural loess catchment (Szczebrzeszyn Roztocze region, SE Poland). Landform Analysis, 17: 39-42.

- Erdas, O., 1993: The effects of using skidders logging operations on mechanical properties of the soil and their biological consequences. Turkish Journal of Agricultural and Forestry. 17: $1-10$.

- Gayoso, J., A.Iroume, 1991: Compaction and soil disturbances from logging in Southern Chile. Ann. Sci. For., 48: 63-71.

- Greene, W.D., W.B.Stuart, 1985: Skidder and tire size effects on soil compaction. South J. App.For., 9(3): 15-17.

- Gulcur F. 1974. Toprağın Fiziksel ve Kimyasal Analiz Metodları. İ.Ü. Orman Fakültesi Yayınları, İ. Ü. Yayın No 1970, O.F. Yay. No. 201, Kutulmuş Matbaası, İstanbul.

- Jamshidi, R., D.Jaeger, N.Raafatnia, M.Tabari, 2008: Influence of two ground-based skidding systems on soil compaction under different slope and gradient conditions. International Journal of Forest Engineering, 19(1): 9-16.

- Jakobsen, B.F., E.L.Greaceri, 1985: Compaction of sandy forest soils by forwarder operations. Soil and Tillage Research, 5(1): 55-70.
- Kalıpsız, A, 1981: İstatistik Yöntemleri. Istanbul Universitesi, Yayın No. 2837, Istanbul.

- Karaoz, O, 1992: Toprakların Su Ekonomisine İlişskin Bazı Fiziksel Özelliklerinin Laboratuarda Belirlenmesi Yöntemleri. İ.Ü. Or. Fak. Der. Seri B, Cilt 39, Sayı 2: 133 - 144.

- Labelle, E.R., D.Jaeger, 2011: Soil compaction caused by cut to length forest operations and possible short term natural rehabilitation of soil density. Soil Sci. Soc. Am. J. 75(6): 2314-2329.

- Lotfalian, M., A.Parsakhoo, 2009: Investigation of forest soil disturbance caused by rubber-tired skidder traffic. International Journal of Natural and Engineering Sciences, 3(1): 79-82.

- Majnounian, B., M. Jourgholami, 2013: Effects of rubber-tired cable skidder on soil compaction in Hyrcanian Forest. Croatian Journal of Forest Engineering, 34(1): 123-135.

- Matangaran, J.R., H.Kobayashi, 1999: The effect of tractor logging on forest soil compaction and growth of Shorea selanica seedlings in Indonesia. J.For.Res., 4: 13-15.

- Melemez, K., 2010: Ergonomic evaluation of tractor vibration in forestry. Suleyman Demirel University, Turkish Journal of Forestry, A(1): 96-108.

- Mc Lean EO. 1982. Soil pH and lime requirement. In: Page, A.L., Miller, R.H., Keeney, D.R. (Eds.), Methods of soil Analysis. Part 2. Chemical and Microbiological Properties Second Edition. Soil Science Society of America Inc. Madison, Wisconsin, USA, pp: 159-224.

- Muntenau, H., A. Apafaian, 2015: Reviewing the soil compaction for cable skidders and animal traction equipment: Implications for the Romanian forets operations. Procedia Environmental Science, Engineering and Management, 2: 129-135.

- Naghdi, R., I. Bagheri, M.Akef, A.Mahdavi, 2007: Soil compaction caused 450C Timberjack wheeled skidder (Shefarood forest, northern Iran). Journal of Forest Science, 53: 314-319.

- Ozdamar, K, 2002: Paket programlar ile istatistik veri analizi. Kaan Kitabevi, Istanbul.

- Ozturk, T., 2014: Productivity and Cost of Rubber Wheel Tired Tractor in a Northern Pine Plantation Forest of Turkey. Baltic Forestry, 20(2): 272-276.

- Pierzchala, M., B. Talbot, R. Astrup, 2004: Estimating Soil Displacement from Timber Extraction Trails in Steep Terrain: Application of an Unmanned Aircraft for 3D Modelling. Forests, 5:1212-1223.

- Schnurr-Pütz, S., E. Baath, G. Guggenberger, H.L. Drake, K. Küsel, 2006: Compaction of forest soil by logging machinery favours occurrence of prokaryotes. FEMS Microbial Ecol., 58(3): 503-516.

- Senol, S, 2004: Parametrik olmayan istatistik yöntemler. Ege Universitesi, Fen Fakultesi Yayın No.190, Izmir.

- Sudherland, B.J., 2003: Preventing soil compaction and rutting in the boreal Forest of Western Canada. FERİC, Advantage Vol.4, No.7, pp.7-8.

- Susnjar, M., D. Horvat, J. Seselj, 2006: Soil compaction in timber skidding in winter conditions. Croatian Journal of Forest Engineering, 27(1): 3-15.

- Wang, J., C.B. LeDoux, P. Edwards, 2007: Changes in soil bulk density resulting from construction and conventional cable skidding using preplanned skid trails. North. J. Appl. For., 24(1): 5-8. 


\section{SAŽETAK}

Ovo se istraživanje bavilo stupnjem zbijenosti tla i kolotraga na traktorskim vlakama i putevima, uzrokovano traktorskim gumama u plantažnoj šumi bora u sjevernoj Turskoj. U istraživanom području odabrana je traktorska vlaka te je izmjeren presjek vlake i puta svakih 20 metara. Izmjerene su promjene na svakom presjeku nakon prolaska traktora, i te su vrijednosti zabilježene. Kao rezultat ove studije prikazane su promjene dubine i zbijenosti tla na vlaci i putu tijekom operacija privlačenja drva. Određena je prosječna širina pogođene površine na traktorskoj vlaci i putu. Rezultati ovoga istraživanja pokazali su da su se dubina kolotraga i zbijenost tla povećali s povećanim prolaskom traktora. Dubina kolotraga postala je značajna nakon 4., 8., 12 ., 16. i 20. prolaska, čime se postigla prosječna dubina od redom 2,6, 3,5, 4,1, 4,6 i 4,9 cm. Penetrometrom su izmjerene vrijednosti presjeka na pet različitih mjesta na traktorskoj vlaci i putu, kao i na šumskom tlu na rubu područja traktorske vlake i puta ( 1 točka).

KLJUČNE RIJEČl: zbijanje tla, kolotrag, privlačenje, traktorska vlaka 